\title{
Entrepreneurial orientation and performance in the context of market dynamism: similarities and differences between Polish and Bulgarian companies
}

\section{Orientacja przedsiębiorcza i wyniki w kontekście dynamizmu rynku: podobieństwa i odmienności między polskimi i bułgarskimi przedsiębiorstwami}

\author{
Anna Wójcik-Karpacz \\ Jarosław Karpacz \\ Daniel Pavlov \\ University of Ruse “Angel Kanchev", e-mail: dpavlov@uni-ruse.bg \\ Joanna Rudawska \\ The Jan Kochanowski University in Kielce, e-mail: joanna.rudawska@gmail.com
}

The Jan Kochanowski University in Kielce, e-mail: anna.wojcik-karpacz@ujk.edu.pl, ORCID: 0000-0002-6303-6778

The Jan Kochanowski University in Kielce, e-mail: jaroslaw.karpacz@ujk.edu.pl, ORCID: 0000-0001-7315-2855

\begin{abstract}
The aim of the study is to identify the similarities and differences regarding the level of entrepreneurial orientation and the performance results between Polish and Bulgarian companies in the context of the market dynamism they operate on. The subject is part of the research stream on discovering the context role in studying the effects of EO. In this research, an international (two-country) sample was used, which sheds light on the occurrence of EO in Polish companies in comparison to Bulgarian companies, with a simultaneous diagnosis of the level of results in these companies and the market dynamism that the companies perform their business with. Quantitative empirical studies were conducted using the CAWI method The research sample included micro, small, medium and large companies operating in Poland and in Bulgaria. Similarities and differences were recognized on the level of entrepreneurial orientation, company results and market dynamism in various perspectives, i.e. the size, the profile of business activities of the company according to PKD and the age of the company.
\end{abstract}

Keywords: entrepreneurial orientation, performance, market dynamism.

\section{Streszczenie}

Celem opracowania jest identyfikacja podobieństw i odmienności w poziomie orientacji przedsiębiorczej i wyników między polskimi i bułgarskimi firmami na tle dynamizmu rynku, na którym one funkcjonują. Tematyka wpisuje się w nurt badań nad odkrywaniem roli kontekstu (dynamizmu rynku w dwóch krajach) w studiowaniu efektów EO. W tym badaniu została wykorzystana międzynarodowa (dwukrajowa) próba, która rzuca światło na występowanie EO w firmach polskich w porównaniu z firmami bułgarskimi, z jednoczesną diagnozą poziomu wyników w tych firmach i dynamizmu rynku, na którym te firmy prowadzą aktywność biznesową. Ilościowe badania empiryczne prowadzone były metodą CAWI. Próba badawcza obejmowała mikro-, małe, średnie i duże firmy funkcjonujące w Polsce i w Bułgarii. Rozpoznano podobieństwa i różnice w poziomie orientacji przedsiębiorczej, wynikach firm i dynamizmie rynku w różnych ujęciach, tj.: rozmiaru, profilu działania firmy według PKD i wieku firmy.

Słowa kluczowe: orientacja przedsiębiorcza, wyniki, dynamizm rynku. 


\section{Introduction}

The contemporary dynamism of the business environment has been forcing businesses to remain competitive by exploring new opportunities. Strategic orientation has been defined as the principles that direct and influence the activities of businesses and that inform the behaviour aimed at exploiting opportunities so as to gain and sustain competitive advantage [Altinay et al. 2016]. One of the strategic orientations is entrepreneurial orientation. Some of the authors suggest that EO is a direct measure of organizational entrepreneurship (e.g. [Kemelgor 2002; Dyduch 2006]). According to the opinion of a number of researchers, these features are also related to entrepreneurial communities with a great need for achievements [Nieman, Nieuwenhuizen 2009]. The research so far has also proved that EO is an important variable explaining the behaviour of companies in emerging economies characterized by new opportunities resulting from the free flow of capital, products and technologies. In such environments, with simultaneously limited regulations, entrepreneurship is a key carrier of the socio-economic development of contemporary societies [Kwiotkowska 2017] and its organizations (entrepreneurship) implicating relatively freely, may often take advantage of opportunities created previously [Bratnicka 2015]. This became an important element of policy both on a national and international level. The growth of the companies is of key importance for the economy of individual countries. Therefore, entrepreneurial orientation is considered as a very important factor in the growth of companies [Karpacz 2018]. The companies need to engage in entrepreneurial activities and create platforms for the exploration of new ideas to broaden their scope for learning and pursue new business endeavours [Altinay et al. 2016].

Most researchers of EO use this fact and conduct the research in the perspective of EO-as-Advantage in different contexts. Rauch and others even suggested that EO is a promising area for creating a set of relevant knowledge about entrepreneurship [Rauch et al. 2009]. Our main intention for quantitative empirical research, whose results are presented in this article, was to broaden the knowledge about entrepreneurial orientation and the results of companies operating in Poland and Bulgaria, as well as market dynamism. The collected results of the research provide the opportunity to conduct comparative analyses, therefore the identification of the similarities and differences on the level of entrepreneurial orientation and the results between Polish and Bulgarian companies in the context of the market dynamism they perform in, is the aim of this article.

\section{Theoretical background}

EO is considered the "driving force behind the organizational pursuit of entrepreneurial activities". It captures a company's institutional embodiment of the entrepreneurial perspective [Kollmann, Stöckmann 2014]. Entrepreneurial orientation (EO) is a strategy-making process that provides organizations with a basis for entrepreneurial decisions and actions with the purpose of creating a competitive advantage. Therefore, entrepreneurial orientation (EO) refers to a firm's strategic organizational position, capturing specific entrepreneurial aspects of decision-making styles, methods, and behaviour. In other words, EO is a driving force for the organizational pursuit of entrepreneurial endeavours and activities. Thus EO is one of the most frequently applied firm-level constructs in entrepreneurship research [Lomberg et al. 2017]. Based on the idea that firms benefit from newness and responsiveness, EO is said to lead to superior performance [Rauch et al. 2009]. There is plentiful empirical evidence confirming the positive relation between EO and the results of the company, whereas the environment of the company and disorders of the environment may have an impact on the relation EO-performance. The impact on performance may be manifold and encompass larger profits, higher growth, and non-financial aspects. Consequently, research testing propositions in the context of EO should capture the overall performance, incorporating different indicators [Kollmann, Stöckmann 2014]. Consistent with the majority of the extant EO research, we consider EO to encompass three dimensions, namely innovativeness, pro-activeness and risk- taking. These three dimensions best represent the conceptual view of an entrepreneurial orientation, even though other conceptualizations add additional dimensions or exclude individual dimensions [Lomberg et al. 2017].

Within the EO framework, innovativeness refers to the tendency to engage in creative processes, experimentation, and the introduction of new products and services, thereby deviating from established practices [Lumpkin, Dess 1996; Rauch et al. 2009].

Pro-activeness refers to opportunity-seeking, forward-looking behaviour that incorporates acting on the future needs and trends ahead of competitors, thereby actively entering new product/market spaces, creating first-mover advantages, and seeking market leadership positions [Lomberg et al. 2017].

Risk taking refers to the tendency towards engaging in highrisk activities with chances of high returns, and also in bold actions in uncertain environments [Lomberg et al. 2017].

The prominence of the EO concept within management research stems from the assumption that EO represents a continuous variable (or the set of variables) upon which all organizations can be positioned or plotted. This assumption contributes to the view that all organizations fall somewhere along a conceptual continuum ranging from conservative (the "low" end) to entrepreneurial (the "high" end) or in a multidimensional conceptual space that captures the domain of "being entrepreneurial" [Covin, Wales 2012]. As such, investigations of EO have targeted organizations' orientations toward entrepreneurial activity irrespective of whether they are young or old, small or large, public or private, etc. Taking in consideration a broad application of EO in previous researches, this concept was also accepted in this empirical research.

\section{Data Collection and sample}

A quantitative empirical survey was conducted from $1^{\text {st }}$ June 2018 to $31^{\text {st }}$ August 2018 under a cooperation agreement between Jan Kochanowski University in Kielce and the University 
of Ruse "Angel Kanchev", The Faculty of Business and Management. The research was conducted using the CAWI (Computer Assisted Web Interviews) method. This technique is based on sending the on-line instrument to the respondents, its completion and return in the same way. The answers were collected in the electronic version of the spreadsheet document, at the same time becoming the database necessary for statistical analyses. This technique has made it easier for us to reach a wide group of respondents from micro, small, medium and large companies, which would be more time-consuming and cost-intensive than other survey techniques in a situation where the territorial research area included not only Poland but also Bulgaria. The use of this technique allowed the respondents to have a sense of anonymity and made it possible to fill in the questionnaire at a convenient time. After the completion of the survey, answers were received from 290 companies, 219 from Polish companies and 71 from Bulgarian companies.

In Tables 1 and 2 the structure of the samples was presented. The grouping of the companies according to their size was carried according to the number of the employees' criterion [Ustawa z dnia 2 lipca 2004 r.]. The part of individual companies in the sample research according to their size is presented in Table 1.

The research sample covered 290 companies, 219 in Poland and 71 in Bulgaria. The largest number were service companies that employed less than 10 employees (84 Polish companies and 14 Bulgarian companies). A smaller group consisted in micro-companies, which indicated production as the basic type of activity (28 Polish companies and 16 Bulgarian companies). However, the Bulgarian micro-companies with a trading profile were a much larger group than the Polish companies (12 Polish companies and 20 Bulgarian companies). The construction industry was represented only by the Polish micro-companies. Small companies (employing from 10 to 49 employees) were a much smaller group than micro-companies. However, Polish small companies (services, production, trading and construction) were more widely represented than Bulgarian companies. Medium-sized companies, similarly to micro and small ones, were represented in each sector by Polish companies rather than by Bulgarian. The smallest group was represented by large companies, including Polish companies functioning in the services and trading sector. In the research sample, there was also a large production company from Bulgaria, therefore most companies in the research sample were micro and small companies. It should be noted that a similar situation is also observed in the structure of the Polish and Bulgarian corporate sector [Raport... 2018].

The grouping of the companies in the research sample was also performed according to the size and age of the companies considering their performance on the market since the start of the business activity. These data were presented in Table 2 .

Table 2 shows that in the research sample the largest number of companies was on the market for 10 years or more, both Polish (60 companies) and Bulgarian (42 companies), a slightly

Table 1 . The structure of the sample research according to the size and profile of the companies, their country and business activity

\begin{tabular}{|c|c|c|c|c|c|c|c|c|c|c|}
\hline \multirow{3}{*}{$\begin{array}{c}\text { The profile of the performance } \\
\text { of the companies according to } \\
\text { PKD (The Polish Classification } \\
\text { of Activities) }\end{array}$} & \multicolumn{10}{|c|}{ The size of the companies (according to the number of the employees) } \\
\hline & \multicolumn{2}{|c|}{$\begin{array}{c}\text { Micro } \\
\text { (up to } 9 \text { employees) }\end{array}$} & \multicolumn{2}{|c|}{$\begin{array}{c}\text { Small } \\
\text { (from } 10 \text { to } 49 \\
\text { employees) }\end{array}$} & \multicolumn{2}{|c|}{$\begin{array}{c}\text { Medium } \\
\text { (from } 50 \text { to } 249 \\
\text { employees) }\end{array}$} & \multicolumn{2}{|c|}{$\begin{array}{c}\text { Large } \\
\text { (over } 250 \\
\text { employees) }\end{array}$} & \multicolumn{2}{|c|}{$\begin{array}{l}\text { The number } \\
\text { of companies }\end{array}$} \\
\hline & POL & BG & POL & BG & POL & BG & POL & BG & POL & BG \\
\hline Services & 84 & 14 & 37 & 5 & 10 & 1 & 3 & 1 & 134 & 21 \\
\hline Production & 28 & 16 & 21 & 6 & 5 & 3 & 0 & 1 & 54 & 26 \\
\hline Trade & 12 & 20 & 7 & 3 & 1 & 0 & 2 & 0 & 22 & 23 \\
\hline Construction & 6 & 0 & 1 & 0 & 2 & 0 & 0 & 0 & 9 & 0 \\
\hline Total & 130 & 51 & 66 & 14 & 18 & 4 & 5 & 2 & 219 & 71 \\
\hline
\end{tabular}

Source: own study.

Table 2. The structure of the sample research according to the size and the age of the companies, their country and business activity

\begin{tabular}{|c|c|c|c|c|c|c|c|c|c|c|}
\hline \multirow{3}{*}{ Age of the company } & \multicolumn{10}{|c|}{ The size of the companies (according to the number of the employees) } \\
\hline & \multicolumn{2}{|c|}{$\begin{array}{c}\text { Micro } \\
\text { (up to } 9 \text { employees) }\end{array}$} & \multicolumn{2}{|c|}{$\begin{array}{c}\text { Small } \\
\text { (from } 10 \text { to } 49 \\
\text { employees) }\end{array}$} & \multicolumn{2}{|c|}{$\begin{array}{c}\text { Medium } \\
\text { (from } 50 \text { to } 249 \\
\text { employees) }\end{array}$} & \multicolumn{2}{|c|}{$\begin{array}{c}\text { Large } \\
\text { (over } 250 \\
\text { employees) }\end{array}$} & \multicolumn{2}{|c|}{$\begin{array}{l}\text { The number } \\
\text { of companies }\end{array}$} \\
\hline & POL & BG & POL & BG & POL & BG & POL & BG & POL & BG \\
\hline A year or less & 20 & 1 & 0 & 0 & 0 & 0 & 0 & 0 & 20 & 1 \\
\hline 2-3 years & 35 & 9 & 12 & 1 & 1 & 0 & 0 & 0 & 48 & 10 \\
\hline 4-6 years & 37 & 9 & 16 & 2 & 3 & 0 & 1 & 0 & 57 & 11 \\
\hline 7-9 years & 14 & 7 & 16 & 0 & 2 & 0 & 2 & 0 & 34 & 7 \\
\hline 10 years or more & 24 & 25 & 22 & 11 & 12 & 4 & 2 & 2 & 60 & 42 \\
\hline Total & 130 & 51 & 66 & 14 & 18 & 4 & 5 & 2 & 219 & 71 \\
\hline
\end{tabular}

Source: own study. 
lower number of Polish companies in the range of 4 to 6 years of activity (57 companies), and two to three years (48 companies). However, the Bulgarian companies in the first group were definitely fewer (11 companies) than the Polish ones (57 companies), similarly as in those in the second group years (48 Polish companies and 11 Bulgarian companies). The 'youngest' companies in the surveyed population are mainly Polish (20). Among the micro-companies that have functioned for 10 years and longer, there were 25 Bulgarian and 24 Polish ones, whilst in other 'age' categories of companies in terms of numbers, Polish companies dominated, with the exception of large companies that have operated on the market for 10 years or more (two Polish and two Bulgarian). Moreover, there were no large companies in the research sample that have functioned on the market for a year or less, or those that have functioned for two to three years. Analysis of the statistical data enabled assembling the profile of Polish and Bulgarian companies, which may provide support in statistical analyses and enable faster detection and clarification of the relations between variables.

\section{Analysis and results}

Tables 3 to 5 contain a comparison of entrepreneurial orientation, environmental dynamism and performance in regard to the size, age and profile of the companies that are contained in the sample.

The first analysis of the variables was performed according to the size of the companies. To do this, a pivot table was created (in subsequent contexts the analysis of variables was similar) presenting the average levels of the variables and the corresponding standard deviations for individual sizes of companies. A comparison of medium variable levels with standard deviations according to the size of companies is presented in Table 3.

Analysis of the results in Table 3 shows that large companies, both Polish and Bulgarian, have a high entrepreneurial orientation (respectively, an average of 5.37 and 4.58). However, large Bulgarian companies are a more diverse group than the Polish ones. This is shown by the recorded values of standard deviation (2.01 - large Bulgarian companies and 0.57 - large Polish companies), meaning that the assessment of the level of entrepreneurial orientation in the group of large Bulgarian companies differs from the arithmetic average by 2.01 points, and in the group of large Polish companies by 1.47 points.

In continuing the analysis of statistical data, it can be noticed that large companies employing over 250 employees assess their results better than other organizations. For large companies, the average for the results is practically identical (5.73 - large Polish companies and 5.50 - large Bulgarian companies). At the same time, both groups of large companies varied little in this respect (the average for the Polish and Bulgarian companies is 0.58 and 0.51 , respectively). As large companies assessed the results of their companies as higher than the results of competitors, this means that they also serve as an empirical indicator of their competitive advantage [Schilke 2014]. However, using simple descriptive statistics to show the high level of entrepreneurial orientation and the high level of company results among large companies automatically indicates the influence of one variable on another [Czakon 2011].

The recorded level of entrepreneurial orientation in micro, small and medium-sized companies functioning in Poland was similar (4.57 points, 4.75 points, 4.55 points, respectively). However, standard deviations show similar differences among the group of micro and small companies (1.13 points, 1.12 points, respectively) and slightly higher among medium-sized companies ( 0.98 points).

The micro, small and medium-sized companies functioning in Poland achieved significantly higher results than their competitors $(4.33,4.61,4.87$, respectively), although they were not significantly higher than their competitors. However, the micro and small companies in Bulgaria achieved slightly lower results than their competitors $(3.85,3.45$, respectively). At the same time, the value of standard deviations $(0.31$ and 0.43 points respectively) indicates that these groups are not very diverse in this respect. The lowest level of results was recorded among the medium-sized companies in Bulgaria (2.58), which achieved much lower results than their competitors, and at the same time in this respect it was a little differentiated group, as the standard deviation was 0.39 points.

In conclusion, the analysis of the levels of average entrepreneurial orientation, the results and standard deviations for individual sizes of Polish and Bulgarian companies related to them, shows that the micro, small and medium companies in

Table 3. Variables examined in relation to the size of companies and the country of their business performance

\begin{tabular}{|c|c|c|c|c|c|c|c|c|c|c|c|c|}
\hline \multirow[t]{2}{*}{$\begin{array}{l}\text { The size of the } \\
\text { company }\end{array}$} & \multicolumn{2}{|c|}{$\begin{array}{c}\text { Entrepreneurial } \\
\text { orientation (mean) }\end{array}$} & \multicolumn{2}{|c|}{$\begin{array}{c}\text { Entrepreneurial } \\
\text { orientation } \\
\text { (standard } \\
\text { deviation) }\end{array}$} & \multicolumn{2}{|c|}{$\begin{array}{l}\text { Market dynamism } \\
\text { (mean) }\end{array}$} & \multicolumn{2}{|c|}{$\begin{array}{c}\text { Market dynamism } \\
\text { (standard } \\
\text { deviation) }\end{array}$} & \multicolumn{2}{|c|}{$\begin{array}{l}\text { Firm performance } \\
\text { (mean) }\end{array}$} & \multicolumn{2}{|c|}{$\begin{array}{c}\text { Firm performance } \\
\text { (standard } \\
\text { deviation) }\end{array}$} \\
\hline & POL & BG & POL & BG & POL & BG & POL & BG & POL & BG & POL & BG \\
\hline Micro & 4.57 & 3.85 & 1.13 & 1.56 & 3.95 & 3.66 & 1.09 & 1.46 & 4.33 & 3.85 & 0.45 & 0.31 \\
\hline Small & 4.75 & 3.89 & 1.12 & 1.33 & 3.97 & 3.48 & 0.92 & 1.33 & 4.61 & 3.45 & 0.44 & 0.43 \\
\hline Medium & 4.55 & 4.17 & 0.98 & 1.31 & 3.56 & 3.38 & 1.20 & 0.76 & 4.87 & 2.58 & 0.65 & 0.39 \\
\hline Large & 5.37 & 4.58 & 0.57 & 2.01 & 5.03 & 3.67 & 0.97 & 1.44 & 5.73 & 5.50 & 0.58 & 0.51 \\
\hline Total & 4.64 & 3.90 & 1.07 & 1.51 & 3.95 & 3.61 & 1.05 & 1.40 & 4.49 & 3.75 & 0.47 & 0.33 \\
\hline
\end{tabular}

Source: own study. 
Poland have a higher entrepreneurial orientation and better results than the Bulgarian companies of the same size. However, the large Bulgarian companies have a slightly higher EO than the large Polish ones, but at the same time they achieve slightly lower results than those achieved by large Polish companies with a slightly lower EO.

Market dynamism, measured with the changes in technology, competition and customers [Wang et al. 2015], was assessed as high only by large companies in Poland. However, in the opinion of the other Polish and Bulgarian companies, the market dynamism was not extremely low or high, which means that in the view of these companies the environment was rather stable.

A similar analysis of statistical data was conducted for the basic type of business activity according to PKD (The Polish Classification of Activities). In order to do this, pivot tables presenting average levels and standard deviations for the basic activity profile of companies were used. A comparison of the average levels of variables according to the type of basic activity on the basis of PKD (The Polish Classification of Activities) codes indicated in the questionnaires is presented in Table 4.

The grouping of companies was based on the answers of respondents who indicated the leading activity of their company according to PKD (The Polish Classification of Activities).

The research results presented in Table 4 show that the Polish companies in general, regardless of the business activity profi- le, are characterized by higher levels of entrepreneurial orientation than the Bulgarian ones. At the same time, the Bulgarian companies are more diverse in this respect than the Polish, as evidenced by the recorded values of standard deviations. Continuing the diagnosis of the EO status among the research sample of companies, for example, Polish construction companies (5.44) are characterized by a high level of entrepreneurial orientation, the production companies have a slightly lower level of EO (4.79), followed by service companies (4.61) and trading (4.11). In this respect, the Polish construction companies are the least diversified group ( 0.88 points), and the most diverse group are trading companies (1.20 points).

In addition, on the basis of statistical data, it can be established that each group of the Polish companies achieved significantly higher results than the Bulgarian ones, and in this context the former were little differentiated, but this differentiation was greater than among their Bulgarian counterparts.

At the same time, the services, production and trading companies, both Polish and Bulgarian, perceived the environment as more stable, and large companies perceived it as moderately dynamic. In such an environment, the Polish companies showed either high or medium EO levels, and the Bulgarian companies were characterized by an average level of EO, as well as high and low, due to their high differentiation.

Another analysis of statistical data was conducted for the age criterion of companies according to the number of years since the company was founded, classifying the number of years into five categories. The reason for the selection of this criterion

Table 4. The examined variables according to the profile of the activity of companies and the country of their business activity

\begin{tabular}{|c|c|c|c|c|c|c|c|c|c|c|c|c|}
\hline \multirow[t]{2}{*}{$\begin{array}{c}\text { The type } \\
\text { of basic activity }\end{array}$} & \multicolumn{2}{|c|}{$\begin{array}{c}\text { Entrepreneurial } \\
\text { orientation (mean) }\end{array}$} & \multicolumn{2}{|c|}{$\begin{array}{c}\text { Entrepreneurial } \\
\text { orientation } \\
\text { (standard deviation) }\end{array}$} & \multicolumn{2}{|c|}{$\begin{array}{l}\text { Market dynamism } \\
\text { (mean) }\end{array}$} & \multicolumn{2}{|c|}{$\begin{array}{l}\text { Market dynamism } \\
\text { (standard } \\
\text { deviation) }\end{array}$} & \multicolumn{2}{|c|}{$\begin{array}{l}\text { Firm performance } \\
\text { (mean) }\end{array}$} & \multicolumn{2}{|c|}{$\begin{array}{c}\text { Firm performance } \\
\text { (standard } \\
\text { deviation) }\end{array}$} \\
\hline & POL & $B G$ & POL & $B G$ & POL & $B G$ & POL & BG & POL & BG & POL & $B G$ \\
\hline Services & 4.61 & 3.89 & 1.09 & 1.51 & 3.98 & 3.16 & 1.07 & 1.47 & 4.40 & 3.76 & 0.46 & 0.27 \\
\hline Production & 4.79 & 3.85 & 0.99 & 1.57 & 3.85 & 3.67 & 0.90 & 1.25 & 4.77 & 3.65 & 0.49 & 0.41 \\
\hline Trade & 4.11 & 3.91 & 1.20 & 1.44 & 3.90 & 3.91 & 1.18 & 1.51 & 4.21 & 3.83 & 0.41 & 0.31 \\
\hline Construction & 5.44 & 0 & 0.88 & 0 & 4.13 & 0 & 1.24 & 0 & 4.89 & 0 & 0.62 & 0 \\
\hline Total & 4.64 & 3.90 & 1.07 & 1.51 & 3.95 & 3.61 & 1.05 & 1.40 & 4.49 & 3.75 & 0.47 & 0.33 \\
\hline
\end{tabular}

Source: own study.

Table 5. The research variables according to the age of companies and the country of their business activity

\begin{tabular}{|c|c|c|c|c|c|c|c|c|c|c|c|c|}
\hline \multirow[t]{2}{*}{$\begin{array}{l}\text { Age of the } \\
\text { company }\end{array}$} & \multicolumn{2}{|c|}{$\begin{array}{c}\text { Entrepreneurial } \\
\text { orientation (mean) }\end{array}$} & \multicolumn{2}{|c|}{$\begin{array}{c}\text { Entrepreneurial } \\
\text { orientation } \\
\text { (standard deviation) }\end{array}$} & \multicolumn{2}{|c|}{$\begin{array}{l}\text { Market dynamism } \\
\text { (mean) }\end{array}$} & \multicolumn{2}{|c|}{$\begin{array}{l}\text { Market dynamism } \\
\text { (standard } \\
\text { deviation) }\end{array}$} & \multicolumn{2}{|c|}{$\begin{array}{l}\text { Firm performance } \\
\text { (mean) }\end{array}$} & \multicolumn{2}{|c|}{$\begin{array}{c}\text { Firm performance } \\
\text { (standard } \\
\text { deviation) }\end{array}$} \\
\hline & POL & BG & POL & BG & POL & BG & POL & BG & POL & BG & POL & BG \\
\hline A year or less & 5.01 & 3.33 & 1.09 & 0.82 & 4.33 & 1.50 & 1.09 & 0.55 & 4.72 & 4.33 & 0.45 & 1.53 \\
\hline 2-3 years & 4.82 & 3.97 & 1.08 & 2.12 & 3.80 & 3.85 & 1.03 & 1.46 & 4.51 & 3.57 & 0.39 & 0.06 \\
\hline 4-6 years & 4.63 & 3.48 & 0.97 & 1.56 & 4.13 & 3.62 & 1.04 & 1.51 & 4.40 & 3.39 & 0.51 & 0.39 \\
\hline 7-9 years & 4.42 & 4.24 & 1.11 & 1.02 & 4.05 & 3.57 & 1.03 & 1.47 & 4.58 & 4.10 & 0.43 & 0.47 \\
\hline 10 years or more & 4.51 & 3.94 & 1.12 & 1.45 & 3.70 & 3.60 & 1.06 & 1.36 & 4.43 & 3.81 & 0.52 & 0.33 \\
\hline Total & 4.64 & 3.90 & 1.07 & 1.51 & 3.95 & 3.61 & 1.05 & 1.40 & 4.49 & 3.75 & 0.47 & 0.33 \\
\hline
\end{tabular}

Source: own study. 
was the findings in the scientific literature, which show that the age of the company has an impact on its competitive advantage [Zahra, Ireland, Hitt 2000]. The average levels and standard deviations of variables according to the period of existence of companies are presented in Table 5.

Analysis of statistical data in Table 5 shows that each age group of the Polish companies has a higher than average level of entrepreneurial orientation, and 'young' companies functioning on the market for one year or even shorter, show a high level of EO and these groups are similarly diversified. Moreover, young organizations assessed the market dynamism as only slightly stronger than moderate, similar impressions were also experienced by the Polish companies in the groups of four to six years and seven to nine years. Other 'age' groups of the Polish companies perceived the environment where they perform business activity as more stable.

However, the companies from Bulgaria show generally much higher than low, and some even (companies functioning on the market for seven to nine years) higher than the average level of EO. The fact is that these companies functioning on the market for 2 to 3 years are the most diverse ones in this respect $(2.12$ points). What is more, all these groups of Polish companies recorded slightly higher results than their competitors, which proves their small but still competitive advantage and practically every 'age' group was similarly varied in this respect.

On the other hand, the Bulgarian companies functioning on the market for one year or less, as well as those functioning from seven to nine years, achieve slightly higher results than their competitors $(4.33,4.10$, respectively). Therefore, we can talk about the occurrence of a competitive balance between these companies and their competitors. However, new companies are the most diverse (1.53 points) in this respect than companies functioning on the market for seven to nine years.

Other 'age' groups of the Bulgarian companies achieved slightly lower results than their competitors, which shows a competitive disadvantage (and these groups are only slightly varied in this respect).

Some of the Bulgarian companies (functioning in the market for two to three years) assessed market dynamism as slightly weaker than moderate, and the remaining age groups of companies assessed its level as low, which means that these companies perceive the environment in which they operate as rather stable.

It can be concluded that in markets with moderate environmental dynamism, companies have a higher entrepreneurial orientation and achieve results better than their competitors (findings based on the results of the Polish companies) than when they function in markets with a more stable environment; when the companies have a lower level of entrepreneurial orientation at the same time they achieve lower results (findings based on the results of the Bulgarian companies).

In the next step, the Mann-Whitney test was applied to test for the differences between the studied constructs between the firms from Poland and those from Bulgaria (Table 6).

The results suggest that means for all dimensions of entrepreneurial orientation, as well as for the one with dimensions of market dynamism, i.e. speed of change in technology and competition and company performance, are significantly higher in

Table 6. Ranking of the Mann-Whitney test and the Mann-Whitney test significance

\begin{tabular}{|c|c|c|c|c|c|}
\hline \multicolumn{6}{|c|}{ Ranking of the Mann-Whitney test } \\
\hline Construct & Dimensions & Country & $\mathrm{N}$ & Mean Rank & Sum of Ranking \\
\hline \multirow[t]{9}{*}{ Entrepreneurial Orientation } & \multirow[t]{3}{*}{ Innovativeness } & Poland & 219 & 156.28 & 34226.00 \\
\hline & & Bulgaria & 71 & 112.24 & 7969.00 \\
\hline & & Total & 290 & & \\
\hline & \multirow[t]{3}{*}{ Pro-activeness } & Poland & 219 & 154.57 & 33850.00 \\
\hline & & Bulgaria & 71 & 117.54 & 8345.00 \\
\hline & & Total & 290 & & \\
\hline & \multirow[t]{3}{*}{ Risk taking } & Poland & 219 & 157.11 & 34406.00 \\
\hline & & Bulgaria & 71 & 109.70 & 7789.00 \\
\hline & & Total & 290 & & \\
\hline \multirow[t]{9}{*}{ Market dynamism } & \multirow{3}{*}{$\begin{array}{l}\text { Speed of change in } \\
\text { technology and competition }\end{array}$} & Poland & 219 & 157.47 & 34487.00 \\
\hline & & Bulgaria & 71 & 108.56 & 7708.00 \\
\hline & & Total & 290 & & \\
\hline & \multirow{3}{*}{$\begin{array}{l}\text { Unpredictability of change } \\
\text { in technology and } \\
\text { competition }\end{array}$} & Poland & 219 & 147.46 & 32293.00 \\
\hline & & Bulgaria & 71 & 139.46 & 9902.00 \\
\hline & & Total & 290 & & \\
\hline & \multirow{3}{*}{$\begin{array}{l}\text { Uncertainty of customer } \\
\text { behaviour }\end{array}$} & Poland & 219 & 146.40 & 32061.50 \\
\hline & & Bulgaria & 71 & 142.73 & 10133.50 \\
\hline & & Total & 290 & & \\
\hline \multirow[t]{3}{*}{ Firm Performance } & \multirow{3}{*}{$\begin{array}{l}\text { Jointly: profitability, growth } \\
\text { in sales, market share }\end{array}$} & Poland & 219 & 154.65 & 33868.50 \\
\hline & & Bulgaria & 71 & 117.27 & 8326.50 \\
\hline & & Total & 290 & & \\
\hline
\end{tabular}


Table 6, cont.

\begin{tabular}{|c|c|c|c|c|c|c|c|}
\hline \multicolumn{8}{|c|}{ Mann-Whitney test significance } \\
\hline Categories & Innovativeness & Pro-activeness & Risk taking & $\begin{array}{l}\text { Speed of change } \\
\text { in technology } \\
\text { and competition }\end{array}$ & $\begin{array}{l}\text { Unpredictability of } \\
\text { change in technology } \\
\text { and competition }\end{array}$ & $\begin{array}{l}\text { Uncertainty } \\
\text { of customer } \\
\text { behaviour }\end{array}$ & $\begin{array}{l}\text { Jointly: profitability, } \\
\text { growth in sales, } \\
\text { market share }\end{array}$ \\
\hline $\begin{array}{l}\text { Mann- } \\
\text { Whitney U }\end{array}$ & 5413.000 & 5789.000 & 5233.00 & 5152.000 & 7346.000 & 7577.500 & 5770.500 \\
\hline Wilcoxon W & 7969.000 & 8345.000 & 7789.00 & 7708.000 & 9902.000 & 10133.500 & 8326.500 \\
\hline $\mathrm{Z}$ & -3.865 & -3.256 & -4.203 & -4.299 & -.702 & -.323 & -3.290 \\
\hline $\begin{array}{l}\text { Asymp. Sig. } \\
\text { (2-tailed) }\end{array}$ & .000 & .001 & .000 & .000 & .483 & .747 & .001 \\
\hline
\end{tabular}

a. Grouping Variable: Country

Source: own study.

the companies from Poland than those from Bulgaria (see the $p$ values in Table 6).

The analysis of subsequent statistical data confirms the findings on the basis of the data in Tables 3 to 5 .

\section{Variables and measures}

Where possible, existing constructs and measures were used to ensure their validity. A description of each scale follows. To study entrepreneurial orientation, we used the 6-item questionnaire developed by Gnizy, Baker, Grinstein [2014] focusing on measuring innovativeness, pro-activeness, and risk-taking orientations of the companies. All the scales were measured using the 7-point Likert scale, while Cronbach alfa for the scale amounted to 0.808 , signifying that the scale is reliable.

To measure environmental dynamism, we used the 6-item questionnaire created by Wang, Senaratne and Rafiq [2015], and that scale focused on speed of change in technology and competition, unpredictability of change in technology and competition, and uncertainty of customer behaviour. Accordingly, these items were assessed on the 7-point Likert scale, and Cronbach's alpha for that scale equalled 0.826 which satisfies the basic reliability criteria.

We measured firm performance using the 3-item scale created by Keh, Nguyen, Ng, [2007], all the items were measured using the 7-point Likert scale, and Cronbach's alpha amounted to 0923 for the three items. However, one item was omitted, i.e. overall performance. All the performance measures of the companies are subjective, according to the perception of the respondent.

\section{Research limitations and suggested research directions}

This study is not without its limitations. First, it relies on the self-reported measures of both EO and company performance by the manager or owner of the surveyed companies.

Secondly, the research findings do not represent the general population, but refer to the surveyed population. Nonetheless, they form the premise to continue the exploration of both the direct relations between entrepreneurial orientation and company performance, as well as the exploration of the effects of the mediating variables, including moderators such as the market dynamism in companies performance. It is recommended to research more thoroughly why companies in different countries show a higher level of EO than in others.

Importantly, we did not stop at diagnosing the state of the variables in the research sample the results of which are presented in this article. In the next step we used the structural equation modelling (SEM) analysis, which in our opinion was indicative due to the fact that this statistical technique allows both to detect differences at the level of individual dimensions of EO and to compare the EO value at a more abstract level. The results of our next research findings are presented in another publication.

\section{Bibliography}

Altinay L., Madanoglu M., De Vita G., Arasli H., Ekinci Y., 2016, The Interface between organizational learning capability, entrepreneurial orientation, and SME growth, Journal of Small Business Management, vol. 54, no. 3, pp. 871-891.

Bratnicka K., 2015, Twórcza przedsiębiorczość organizacyjna, Studia Ekonomiczne. Zeszyty Naukowe Uniwersytetu Ekonomicznego w Katowicach, no. 2, pp. 23-34.

Covin J.G., Wales W.J., 2012, The measurement of entrepreneurial orientation, Entrepreneurship Theory \& Practice, vol. 36, no. 4, pp. 677-702.

Czakon W., 2011, Podstawy metodologii badań w naukach o zarządzaniu, Oficyna a Wolters Kluwer business, Warszawa, pp. 106-107.

Dyduch W., 2006, Badanie poziomu przedsiębiorczości organizacyjnej w polskich firmach, [in:] Koncepcje i narzędzia zarządzania strategicznego, M. Romanowska, P. Wachowiak (ed.), Oficyna Wydawnicza Szkoły Głównej Handlowej w Warszawie, Warszawa, pp. 93-106.

Gnizy I., Baker W.E., Grinstein A., 2014, Proactive learning culture: a dynamic capability and key success factor for SMEs entering foreign markets, International Marketing Review, vol. 31, no. 5, pp. 477-505.

Karpacz J., 2018, Orientacja przedsiębiorcza a rozwój zdolności dynamicznych - ujęcie literaturowe, Przedsiębiorczość i Zarządzanie, t. 19, z. 3, cz. 1, pp. 109-126. 
Keh H.T., Nguyen T.T.M., Ng H.P., 2007, The effects of entrepreneurial orientation and marketing information on the performance of SMEs, Journal of Business Venturing, vol. 22, pp. 592-611.

Kemelgor B.H., 2002, A comparative analysis of corporate entrepreneurial orientation between selected firms in the Netherlands and the USA, Entrepreneurship \& Regional Development, vol. 14, pp. 67-87.

Kollmann T., Stöckmann Ch., 2014, Filling the entrepreneurial orientation-performance gap: the mediating effects of exploratory and exploitative innovations, Entrepreneurship Theory \& Practice, vol. 39, no. 5, pp. 1001-1026

Kwiotkowska A., 2017, Wymiary orientacji przedsiębiorczej - wyniki badań empirycznych, Zeszyty Naukowe Politechniki Śląskiej, nr 1974, pp. 257-269.

Le Roux I., Bengesi K.M.K., 2014, Dimensions of entrepreneurial orientation and small and medium enterprise performance in emerging economies, Development Southern Africa, vol. 31, no. 4, pp. 606-624.

Lomberg C., Urbig D., Stöckmann Ch., Marino L.D., Dickson P.H., 2017, Entrepreneurial orientation: The dimensions' shared effects in explaining firm performance, Entrepreneurship Theory \& Practice, vol. 41, no. 6, pp. 973-998.

Lumpkin G.T., Dess G.G., 1996, Clarifying the entrepreneurial orientation construct and linking it to performance, Academy of Management Review, vol. 21, no. 1, pp. 135-172

Nieman G., Nieuwenhuizen C., 2009, Entrepreneurship: a South Africa Perspective (2nd ed.), Van Schaiks, Pretoria.
Raport o stanie sektora małych i średnich przedsiębiorstw w Polsce, Polska Agencja Rozwoju Przedsiębiorczości, Warszawa 2018, pp. 8-11.

Rauch A., Wiklund J., Frese M., Lumpkin G.T., 2009, Entrepreneurial orientation and business performance: an assessment of past research and suggestions for the future, Entrepreneurship Theory \& Practice, vol. 33, pp. 761-786.

Schilke 0., 2014, On the contingent value of dynamic capabilities for competitive advantage: the nonlinear moderating effect of environmental dynamism, Strategic Management Journal, vol. 35, pp. 179-203.

Ustawa z dnia 2 lipca 2004 r. o swobodzie działalności gospodarczej (Dz.U. 2004, nr 173, poz. 1807).

Wang C.L., Senaratne Ch., Rafiq M., 2015, Success traps, dynamic capabilities and firm performance, British Journal of Management, vol. 26 , pp. 26-44.

Wójcik-Karpacz A., 2016, Dobór miar do pomiaru orientacji przedsiębiorczej: dylematy i propozycje rozwiazań, Prace Naukowe Uniwersytetu Ekonomicznego we Wrocławiu, nr 444, pp. 594-608.

Zahra S.A., Ireland R.D., Hitt M.A., 2000, International expansion by new venture firms: International diversity, mode of market entry, technological learning and performance, Academy of Management Journal, vol. 43, no. 5, pp. 925-950 . 